\title{
Structural Proteins of Equine Arteritis Virus
}

\author{
ANTOINE A. F. DE VRIES, EWAN D. CHIRNSIDE, $†$ MARIAN C. HORZINEK, \\ AND PETER J. M. ROTTIER* \\ Institute of Virology, Department of Infectious Diseases and Immunology, \\ Veterinary Faculty, University of Utrecht, Yalelaan 1, \\ 3584 CL Utrecht, The Netherlands
}

Received 29 June 1992/Accepted 28 July 1992

\begin{abstract}
We have recently shown that the genome of equine arteritis virus (EAV) contains seven open reading frames (ORFs). We now present data on the structural proteins of EAV and the assignment of their respective genes. Virions are composed of a 14-kDa nucleocapsid protein $(N)$ and three membrane proteins designated $M, G_{S}$, and $G_{L} \cdot M$ is an unglycosylated protein of $16 \mathrm{kDa}$, and $G_{S}$ and $G_{L}$ are $N$-glycosylated proteins of 25 and 30 to $42 \mathrm{kDa}$, respectively. The broad size distribution of $G_{L}$ results from heterogeneous $N$-acetyllactosamine addition since it is susceptible to digestion by endo- $\beta$-galactosidase. Using monospecific antisera as well as an antivirion serum, and by expression of individual ORFs, the genes for the structural proteins were identified: ORF 7 codes for $N$, ORF 6 for $M$, ORF 5 for $G_{L}$, and ORF 2 for $G_{S}$. With the exception of $G_{S}$, the proteins are about equally abundant in EAV virions, being present at a molar ratio of $3(N): 2(M): 3\left(G_{L}\right)$. The $G_{S}$ protein, which is expressed at a level similar to that of $M$ in infected cells, is strikingly underrepresented in virus particles (1 to $2 \%$ ). Our data justify a distinct taxonomic position for EAV, together with lactate dehydrogenase-elevating virus and simian hemorrhagic fever virus; although coronavirus- and toroviruslike in features of transcription and translation, the virion architecture of EAV is fundamentally different.
\end{abstract}

Equine arteritis virus (EAV) was first isolated from lung tissue of a fetus aborted during an endemic in standardbred horses (10). Seroepidemiological surveys indicate that the virus is widespread in the horse population $(23,34,36)$, but it only rarely causes disease. A single serotype has been recognized (37), and little genetic variation appears to exist among different EAV isolates $(6,38)$. On the other hand, the clinical signs of infection are extremely variable. In acute disease, symptoms commonly include anorexia, depression, pyrexia, limb and palpebral edema, conjunctivitis, lacrimation, and rhinitis. In pregnant mares, the virus may cause abortion at high rates. Infected stallions may suffer from edema of the sheath and scrotum $(21,22,37)$. A fatal outcome of disease has been reported in both natural and experimental infections, but most natural infections are either mild or subclinical. The virus is transmitted by the respiratory and venereal routes and, to a lesser extent, by indirect contact with contaminated fomites during the acute phase of infection (22). Stallions may become persistently infected and shed virus from their reproductive tract (39); virus persistence has not been noted in mares.

EAV is a small, enveloped, positive-strand RNA virus. On the basis of its physicochemical properties and virion architecture, EAV was originally classified as a togavirus $(19,20$, 42). The spherical virus particles are 45 to $70 \mathrm{~nm}$ in diameter and have a buoyant density in sucrose of 1.17 to $1.20 \mathrm{~g} / \mathrm{ml}$ $(19,25)$. The virions consist of an isometric nucleocapsid of about $35 \mathrm{~nm}$ which is surrounded by an envelope with ringlike surface substructures $(20,25)$. The nucleocapsid is composed of an infectious, polyadenylated, single-stranded genomic RNA with a size of $12.7 \mathrm{~kb}(7)$ and a 12 - to $14-\mathrm{kDa}$ phosphorylated core protein $(24,58)$. The envelope contains a 14- to $16-\mathrm{kDa}$ unglycosylated protein and a number of

\footnotetext{
* Corresponding author.

$\dagger$ Present address: Equine Virology Unit, The Animal Health Trust, Lanwades Park, Kennett, Suffolk, England CB8 7PN.
}

glycoproteins $(24,51,58)$; the latter have not been unambiguously defined. In some studies, a glycosylated $21-\mathrm{kDa}$ protein has been detected, while in others, a heterogeneously migrating set of glycoproteins in the size range of 28 to $40 \mathrm{kDa}$ has been reported. In contrast to alphaviruses and rubiviruses, assembly of EAV takes place by intracellular budding only (33), and multiple subgenomic RNAs are synthesized in EAV-infected cells (50). In view of these observations, the virus was assigned to the novel genus arterivirus (55).

We have recently shown that EAV resembles coronaviruses and toroviruses in its genome organization, gene expression strategy, and replicase gene. The viral genome embodies seven open reading frames (ORFs 1 to 7), each of which is preceded by the sequence $5^{\prime}$ UCAAC $3^{\prime}$ (7). This conserved motif is involved in the transcription of six subgenomic mRNAs (RNAs 2 to 7) which form a 3' coterminal nested set with genomic RNA (9). The subgenomic mRNAs of EAV are composed of leader and body sequences which are not contiguous on the viral genome. The common leader sequence of 207 nucleotides is derived from the extreme $5^{\prime}$ end of the viral genome (9). The joining of leader and body sequences occurs at the $5^{\prime}$ UCAAC 3 ' sites located upstream of the ORFs. Except for the smallest mRNA (RNA 7), the intracellular viral RNAs are thus structurally polycistronic. EAV ORF 1, which comprises the 5' three-fourths of the genome, is expressed from the genomic RNA (RNA 1). It actually consists of two overlapping ORFs which occupy different reading frames. The expression of the second ORF (ORF 1b) involves ribosomal frameshifting (7). EAV ORFs 2 to 7 are expressed from the subgenomic mRNAs, which are probably functionally monocistronic, i.e., only their respective $5^{\prime}$ ORFs are translated. Since ORF 1 shares four conserved amino acid domains with the polymerases of coronaviruses and toroviruses and translation of RNA 7 yields a product which comigrates with the nucleocapsid protein (51), a coronaviruslike gene order of 5'-polymeraseenvelope proteins-nucleocapsid protein- $3^{\prime}$ has been pro- 
posed for the EAV genome (7). Apart from these common traits, notable differences from coronaviruses and toroviruses are the smaller virion and genome sizes, the isometric nucleocapsid architecture, and the absence of prominent spikes (peplomers) on EAV virions.

To investigate further the evolutionary relationship of arteriviruses with coronaviruses and toroviruses, we studied the structural proteins of EAV and identified the corresponding genes.

\section{MATERIALS AND METHODS}

Cells and viruses. Cells were maintained in Dulbecco's modified Eagle's medium (DMEM) supplemented with $10 \%$ heat-inactivated fetal calf serum (FCS), $100 \mathrm{IU}$ of penicillin per $\mathrm{ml}$, and $100 \mu \mathrm{g}$ of streptomycin per ml. The Bucyrus strain of EAV (10) was propagated in lines of baby hamster kidney (BHK-21) and rabbit kidney (RK-13) cells. To prepare concentrated virus, subconfluent monolayers of BHK-21 cells were rinsed twice with phosphate-buffered saline (PBS) containing $50 \mu \mathrm{g}$ of DEAE-dextran per $\mathrm{ml}$ and infected with plaque-purified virus (50) at a multiplicity of infection (MOI) of $10^{-2}$ PFU per cell. After $1 \mathrm{~h}$, the inoculum was replaced by DMEM-10\% FCS, and the cultures were further incubated for 50 to $60 \mathrm{~h}$ at $37^{\circ} \mathrm{C}$. At the stage of a pronounced cytopathic effect, the medium was harvested, clarified by low-speed centrifugation, mixed with an equal volume of ice-cold $20 \%$ polyethylene glycol (PEG) 6000 in $20 \mathrm{mM}$ Tris- $\mathrm{HCl}(\mathrm{pH} \mathrm{7.6)-100} \mathrm{mM} \mathrm{NaCl}-1 \mathrm{mM}$ EDTA, and stirred slowly overnight at $4^{\circ} \mathrm{C}$. The pellet obtained after centrifugation for $30 \mathrm{~min}$ at $10^{4} \times g$ and $4^{\circ} \mathrm{C}$ was gently suspended in the same buffer.

Wild-type vaccinia virus strain WR was provided by $G$. Wertz, and a recombinant vaccinia virus expressing the bacteriophage T7 RNA polymerase gene (vTF7-3) was obtained from $B$. Moss. To generate vaccinia virus recombinants, we used HeLa, human 143 thymidine kinase-negative, and RK-13 cells.

cDNA synthesis, cloning, and nucleotide sequence analysis. The preparation of cDNA libraries from poly $(A)^{+}$RNA of EAV-infected BHK-21 cells and from viral genomic RNA and the mapping and DNA sequence analysis of virusspecific cDNA clones have been described previously $(7,9)$.

Plasmid construction. Recombinant DNA techniques were performed essentially as described by Sambrook et al. (45). ORF 7 was cloned behind the T7 promoter of pBluescript $\mathrm{KS}(+)$ by ligating a 0.55-kb HindIII fragment from EAV cDNA clone 008 (Fig. 1) into the multiple cloning site of the vector to generate plasmid pAVI07. In a separate experiment, the $0.55-\mathrm{kb}$ HindIII fragment was blunt ended with the Klenow fragment of DNA polymerase I and cloned into the SmaI site of the vaccinia virus insertion vector pSC11 (5) (obtained from B. Moss), yielding plasmid pAVE07. The cloning of ORF 6 behind a T7 promoter involved insertion of a 556-bp ClaI-FspI fragment from clone 106 (Fig. 1) into ClaI- and SmaI-digested pBluescript SK $(-)$ to produce pAVI16. Initially, ORF 5 was placed behind a T7 promoter by ligation of a 1,243-bp DraI-HindIII fragment from clone 008 (Fig. 1) into SmaI- and HindIII-digested pBS(+) to yield pAVI05. Subsequently, we constructed pAVI15 by recloning the 0.9-kb $S a c I-X b a I$ fragment from pAVI05 into the polylinker region of pBluescript $\mathrm{KS}(+)$. The plasmid pAVI02, which has ORF 2 positioned downstream of a T7 promoter, was obtained by insertion of a filled-in 828-bp DdeI fragment from EAV cDNA clone 535 (Fig. 1) into SmaI-digested pBluescript $\mathrm{KS}(+)$. The orientation of the

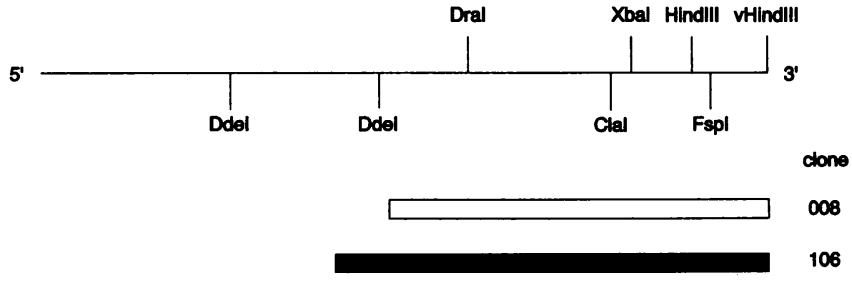

- 535

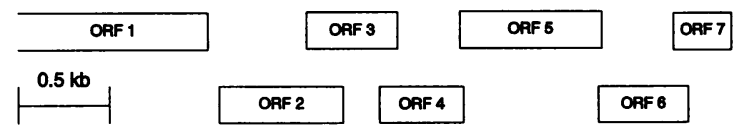

FIG. 1. Physical map of the $3^{\prime}$ end of the viral genome. The cDNA clones and restriction enzyme recognition sites used to insert EAV ORFs 7, 6, 5, and 2 in expression vectors are indicated. Black bars symbolize genomic cDNA clones, and the open bar represents a cDNA clone synthesized on poly $(A)^{+}$RNA from virus-infected BHK-21 cells. The overlapping parts of the oligo(dT)-positive cDNA clones 008 and 106 contain identical nucleotide sequences. The letter $v$ indicates that the HindIII site located at the extreme $3^{\prime}$ terminus of the physical map is derived from the cloning vector. The genome positions of EAV ORFs 2 to 7 and the $3^{\prime}$ end of the viral replicase gene (ORF 1) are also shown.

inserts was verified by restriction enzyme digestions, and the nucleotide sequence of the ORFs was confirmed by sequencing alkali-denatured plasmid DNA with a T7 DNA polymerase sequencing kit (Pharmacia) and $\left[\alpha^{-35}\right.$ S]dATP $(>1,000$ $\mathrm{Ci} / \mathrm{mmol}$; Amersham).

Preparation of antisera. All immune sera were obtained after subcutaneous injections of New Zealand White rabbits. A serum directed against the structural proteins of EAV was prepared by multiple inoculations with purified virions. The virus had been grown in RK-13 cells, concentrated by PEG precipitation, and purified in a 20 to $50 \%$ (wt/wt) sucrose gradient. The animals were injected with $\pm 10^{9}$ PFU of EAV at monthly intervals. For primary immunization, the antigen was mixed with an equal volume of Freund's complete adjuvant, and for the booster injections, Freund's incomplete adjuvant was used.

An antiserum directed against the extreme carboxy terminus of the ORF 7 protein was obtained after immunization with the synthetic peptide SP07 $\left(\mathrm{NH}_{2}\right.$-Tyr-Trp-Val-Pro-ThrLys-Gln-Ile-Gln-Arg-Lys-Val-Ala-Pro-Pro-Ala-Gly-Pro$\mathrm{COOH})$. To produce antibodies exclusively directed against the ORF 6 product, we injected rabbits with the synthetic peptide SP06 $\left(\mathrm{NH}_{2}\right.$-Tyr-Ala-Gly-Arg-Leu-Phe-Ser-Lys-ArgThr-Ala-Ala-Thr-Ala-Tyr-Lys-Leu-Gln-COOH) derived from the carboxy terminus of the protein. Finally, an antiserum against the ORF 2 protein was obtained by using the carboxy-terminal synthetic peptide SPO2 $\left(\mathrm{NH}_{2}\right.$-Cys-Pro-SerArg-Arg-Thr-Ser-Ser-Gly-Thr-Leu-Pro-Arg-Arg-Lys-IleLeu-COOH) for immunization. The peptides SP07 and SP06 were synthesized on a MilliGen/Biosearch 9500 peptide synthesizer by the solid phase t-BOC method; SP02 was produced on a MilliGen/Biosearch 9400 Excell peptide synthesizer by the solid-phase Fmoc procedure (48). To increase the immunogenicity of the peptides, we conjugated SP07 and SP06 to keyhole limpet hemocyanin using limiting amounts of glutaraldehyde (17). SP02 was coupled via its amino-terminal cysteine residue to keyhole limpet hemocyanin after activation of the carrier protein with $\boldsymbol{m}$-maleimi- 
dobenzoyl- $N$-hydroxysuccinimide ester (45). In all cases, the rabbits received $1 \mathrm{mg}$ of conjugate in Freund's complete adjuvant and were boostered at monthly intervals with Freund's incomplete adjuvant.

Isolation of vaccinia virus recombinants. The procedure to isolate vaccinia virus recombinants was adopted from Mackett et al. (32). Briefly, $10-\mathrm{cm}^{2}$ subconfluent monolayers of HeLa cells were infected at a low MOI with wild-type vaccinia virus (strain WR) and transfected with a calcium phosphate precipitate of $5 \mu \mathrm{g}$ of pAVE07 (16). Recombinant vaccinia viruses were selected on thymidine kinase-negative-cells in the presence of $25 \mu \mathrm{g}$ of 5-bromodeoxyuridine per $\mathrm{ml}$ and visually screened with an agar overlay containing 5-bromo-4-chloro-3-indolyl- $\beta$-D-galactopyranoside (X-Gal). After two rounds of plaque purification, a large stock of recombinant virus (vAVE07) was grown in RK-13 cells.

Transfection and infection with recombinant vaccinia viruses. Infection of $\mathrm{BHK}-21$ cells with the vaccinia virus recombinant vAVE07 was done in serum-free medium at an MOI of $10 \mathrm{PFU}$ per cell. After $1 \mathrm{~h}$ at $37^{\circ} \mathrm{C}$, the inoculum was replaced by DMEM-10\% FCS, and the cells were further incubated for $3.5 \mathrm{~h}$ before starvation and radiolabeling. Transfection of BHK-21 cells with the plasmid pAVI16, pAVI15, or pAVI02 was mediated by cationic liposomes (11). To $20-\mathrm{cm}^{2}$ subconfluent monolayers of BHK-21 cells, $10 \mu \mathrm{g}$ of plasmid DNA and $15 \mu \mathrm{l}$ of Lipofectin (Bethesda Research Laboratories) were applied, according to the manufacturer's instructions. After incubation for $5 \mathrm{~h}$ at $37^{\circ} \mathrm{C}$, the cells were infected with the vaccinia virus recombinant vTF7-3 expressing the bacteriophage T7 RNA polymerase (13) at an MOI of 10. Metabolic labeling was started at $10 \mathrm{~h}$ after transfection.

Radioactive labeling of intracellular proteins. Subconfluent monolayers of BHK-21 cells were washed twice with PBS containing $50 \mu \mathrm{g}$ of DEAE-dextran per $\mathrm{ml}$ and infected with EAV at an MOI of $\geq 20$. To stabilize the virus and to enhance adsorption to cells, we prepared the inoculum in PBS-DEAE containing $2 \%$ FCS. After incubation for $1 \mathrm{~h}$ at $37^{\circ} \mathrm{C}$, the inoculum was replaced by DMEM-10\% FCS, and the cells were kept for $6.5 \mathrm{~h}$ at $39.5^{\circ} \mathrm{C}$. At $7.5 \mathrm{~h}$ postinfection (p.i.), the medium was removed, the cells were rinsed with PBS, and methionine-free medium was added to the cells. After starvation for $30 \mathrm{~min}, 100 \mu \mathrm{Ci}$ of Tran $\left.{ }^{35} \mathrm{~S}\right]$-label $(>1,000 \mathrm{Ci} /$ mmol; ICN) per ml was added, and the cells were incubated for $20 \mathrm{~min}$ at $37^{\circ} \mathrm{C}$. In one experiment, labeling was followed by a 2 -h chase with DMEM supplemented with $10 \%$ FCS and $2 \mathrm{mM}$ nonradioactive methionine. The cells were then rinsed with ice-cold PBS and lysed in $20 \mathrm{mM}$ Tris- $\mathrm{HCl}$ (pH 7.6)-150 $\mathrm{mM} \mathrm{NaCl}-1 \%$ Nonidet P-40 (NP-40)-0.5\% sodium deoxycholate- $0.1 \%$ sodium dodecyl sulfate (SDS) containing $1 \mu \mathrm{g}$ of aprotinin, leupeptin, and pepstatin A per $\mathrm{ml}$. The lysates were centrifuged for $20 \mathrm{~min}$ at $10^{4} \times g$ and $4^{\circ} \mathrm{C}$, the pellets were discarded, and the supernatants were supplemented with EDTA to a final concentration of $5 \mathrm{mM}$. The same labeling regimen and cell lysis procedure were used when EAV proteins were expressed from the vaccinia virus recombinant vAVE07 or from the recombinant plasmids pAVI16, pAVI15, and pAVI02.

Preparation of radiolabeled virions. Subconfluent monolayers of BHK-21 cells were infected with EAV at a high MOI as described above. At $7 \mathrm{~h}$ p.i., the medium was replaced by methionine-free or cysteine-free medium containing $2 \% \mathrm{FCS}$ and $100 \mu \mathrm{Ci}$ of $\mathrm{L}-\left[{ }^{35} \mathrm{~S}\right]$ methionine or $\mathrm{L}-\left[{ }^{35} \mathrm{~S}\right]$ cysteine $(>1,000 \mathrm{Ci} / \mathrm{mmol}$; ICN $)$ per ml, respectively. At 10.5 h p.i., 0.2 volume of DMEM-10\% FCS was added to the radioactive medium, and the cells were further incubated for $3.5 \mathrm{~h}$ at $39.5^{\circ} \mathrm{C}$. Finally, an excess of methionine or cysteine was added, and the incubation was continued for 30 min. The medium was then collected, and the virus was purified by PEG precipitation and sucrose gradient fractionation (50).

Immunoprecipitation and gel electrophoresis. Crude protein samples were diluted 10 - to 20 -fold in immunoprecipitation buffer (20 mM Tris- $\mathrm{HCl}$ [pH 7.6], $150 \mathrm{mM} \mathrm{NaCl}, 5 \mathrm{mM}$ EDTA, $0.5 \%$ NP-40, $0.1 \%$ sodium deoxycholate, $1 \mu \mathrm{g}$ of protease inhibitors per $\mathrm{ml}$ ) containing either $0.1 \%$ SDS (antivirion and anti-SP07 serum) or $0.25 \%$ SDS (anti-SP06 and anti-SP02 serum). After the addition of $3 \mu$ l of the rabbit serum, the samples were incubated overnight at $4^{\circ} \mathrm{C}$. The next day, $22.5 \mu$ l of a $10 \%$ suspension of formaldehyde-fixed and heat-inactivated Staphylococcus aureus cells (Pansorbin; Calbiochem) was added, and the samples were incubated for $\geq 2 \mathrm{~h}$ at $4^{\circ} \mathrm{C}$. The immune complexes were then collected by centrifugation and washed three times in $20 \mathrm{mM}$ Tris- $\mathrm{HCl}$ (pH 7.6)-150 mM NaCl-5 mM EDTA-0.1\% NP-40 and once in $20 \mathrm{mM}$ Tris- $\mathrm{HCl}(\mathrm{pH} \mathrm{7.6)-0.1 \%} \mathrm{NP-40.} \mathrm{The}$ resulting pellets were resuspended in $25 \mu \mathrm{l}$ of Laemmli sample buffer and incubated at room temperature for $\geq 15$ min. After centrifugation for $2.5 \mathrm{~min}$ at $10^{4} \times \mathrm{g}$, the supernatants were analyzed in SDS-15\% polyacrylamide gels (30). Alternatively, the immunoprecipitates were subjected to endoglycosidase treatment before gel electrophoresis.

Endoglycosidase treatment. Immunoprecipitates were resuspended in $40 \mu$ lof endoglycosidase buffer $(50 \mathrm{mM}$ sodium phosphate [pH 6.8], 20 mM EDTA, 1\% NP-40, 0.15\% SDS, $1 \%$ 2-mercaptoethanol containing $1 \mu \mathrm{g}$ each of aprotinin, leupeptin, and pepstatin $\mathrm{A}$ per $\mathrm{ml}$ ) and split in equal portions. One of the aliquots was supplemented with $100 \mathrm{mU}$ of endoglycosidase $\mathrm{F} / \mathrm{N}$-glycosidase $\mathrm{F}$ (glyco F) (Boehringer Mannheim), and both portions were gently shaken overnight at $30^{\circ} \mathrm{C}$. Subsequently, the samples were centrifuged for 2.5 min at $10^{4} \times g$, and the pellets were mixed with $25 \mu \mathrm{l}$ of Laemmli sample buffer. $\left[{ }^{35} \mathrm{~S}\right]$ methionine-labeled virus was dissolved in $20 \mu \mathrm{l}$ of endoglycosidase buffer, treated overnight at $30^{\circ} \mathrm{C}$ with $100 \mathrm{mU}$ of enzyme, and supplemented with $10 \mu$ l of $3 \times$ Laemmli sample buffer. Endo- $\beta$-galactosidase (endo- $\beta$ ) (from Bacteroides fragilis; Boehringer Mannheim) digestions were performed in $50 \mathrm{mM}$ sodium acetate (pH 5.75)-200 $\mu \mathrm{g}$ of acetylated bovine serum albumin per $\mathrm{ml}$ (New England Biolabs) $-1 \mu \mathrm{g}$ of protease inhibitors per $\mathrm{ml}$. The incubations were done overnight at $37^{\circ} \mathrm{C}$ with $2 \mathrm{mU}$ of enzyme per reaction.

Fluorography and quantification. Gels were impregnated with 2,5-diphenyloxazole (2), dried on Whatman 3MM filter paper, and exposed at $-70^{\circ} \mathrm{C}$ to hypersensitized Fuji RX films. The relative amounts of radiolabeled virion proteins in the virus preparation were determined directly from a dried gel by using a PhosphoImager 400 scanning apparatus equipped with version 3.2 of the software package ImageQuant (Molecular Dynamics).

Computer analysis of polypeptide sequences. Deduced protein sequences were analyzed with the aid of the Sequence Analysis Software Package for VAX/VMS computers (version 6.2; University of Wisconsin Genetics Computer Group). To identify specific signals in polypeptide sequences, we used release 6.10 of the PROSITE protein pattern data base (1). Signal sequences were evaluated by using the weight-matrix table composed by von Heijne (54). 
TABLE 1. Predicted features of EAV ORF 2 to 7 translation products

\begin{tabular}{ccccccc}
\hline ORF & Amino acids & Molecular wt $\left(10^{3}\right)$ & Cys/Met & Net charge & pI & Motifs \\
\hline 7 & 110 & 12.3 & $0 / 4$ & +11 & 12.27 & 3 phosphorylation \\
6 & 162 & 17.7 & $1 / 5$ & +7 & 10.68 & 1 myristoylation \\
5 & 255 & $28.7\left(26.7^{b}\right)$ & $8 / 7$ & -8 & 4.85 & 1 N-glycosylation; leucine zipper \\
4 & 152 & $17.2\left(14.9^{b}\right)$ & $8 / 2$ & +4 & 8.26 & 3 N-glycosylation; zinc finger \\
3 & 163 & $18.1\left(15.5^{b}\right)$ & $9 / 4$ & +1 & 7.61 & 6 N-glycosylation; leucine zipper \\
2 & 227 & $25.6\left(22.7^{b}\right)$ & $6 / 6$ & +5 & 8.72 & 1 N-glycosylation \\
\hline
\end{tabular}

${ }^{a}$ At neutral pH.

${ }^{b}$ Molecular weight corrected for removal of the signal sequence.

\section{RESULTS}

Computer analysis of EAV ORFs 2 to 7. Seven ORFs were identified by sequence analysis of cDNA clones covering the EAV genome (Fig. 1). On the basis of similarities in amino acid sequence and expression strategy with the polymerase gene of coronaviruses and toroviruses, we assigned viral replicase functions to EAV ORF 1 (7). In search of the structural protein genes, a computer analysis was performed on the deduced amino acid sequences of EAV ORFs 2 to 7. The resulting features of the proteins are summarized in Table 1 , and the concomitant hydrophobicity plots are depicted in Fig. 2.

On the basis of a predicted molecular weight of 12,300 , a high content of basic amino acids, and its hydrophilic nature, we expected the translation product of ORF 7 to be the EAV nucleocapsid (N) protein. The expression products of ORFs 2 to 6 all have hydropathy profiles reminiscent of membrane (M) proteins. The ORF 6 product lacks a potential amino-

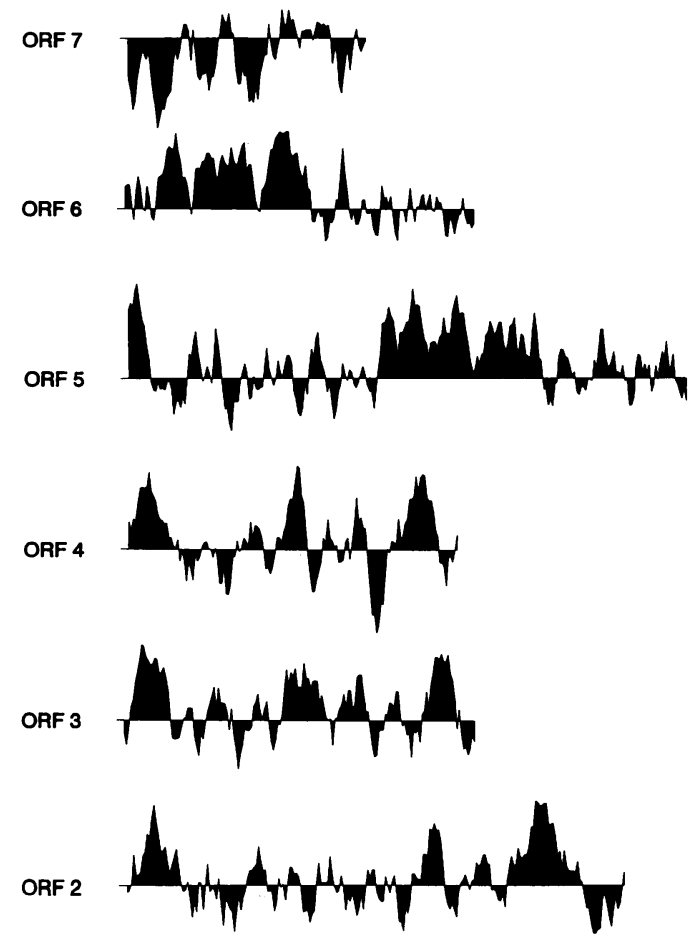

FIG. 2. Hydropathy profiles of the translation products of EAV ORFs 2 to 7 determined by the method of Kyte and Doolittle (29) with a seven-residue moving window. Peaks extending upward indicate hydrophobic domains, and those pointing downward correspond to hydrophilic regions. terminal signal sequence and contains three potential transmembrane regions. The translation products of ORFs 2 to 5 each possess a hydrophobic amino terminus likely to function as a signal sequence. They all have at least one additional hydrophobic domain located more toward the carboxy terminus which may serve as a membrane anchor. The calculated sizes of the translation products of ORFs 2 to 6 range from 17.2 to $28.7 \mathrm{kDa}$. The ORF 6 protein lacks possible $\mathrm{N}$-glycosylation sites, and the translation products of ORFs 2 to 5 contain one, six, three, and one potential $\mathrm{N}$-glycosylation site, respectively.

Identification of structural proteins. To establish unequivocally the number and size of the EAV structural proteins, $\left[{ }^{35}\right.$ S]methionine-labeled virus was purified from the culture medium of EAV-infected BHK-21 cells and analyzed by SDS-polyacrylamide gel electrophoresis (PAGE). A set of four structural proteins, the largest of which appeared as a smear, was routinely observed (Fig. 3a); their molecular weights were estimated as $14,000,16,000,25,000$, and 30,000 to 42,000 .

To identify $\mathrm{N}$-glycosylated proteins and to investigate the nature of the 30 - to $42-\mathrm{kDa}$ smear, we treated virus with glyco $\mathrm{F}$, which cleaves off $N$-glycans. By this treatment, the smear was converted to a discrete band of $27 \mathrm{kDa}$ (Fig. 3a) and therefore represents a single protein whose typical appearance in gel presumably results from heterogeneity in $\mathrm{N}$-glycosylation. As a result of aggregation, part of the deglycosylated 30 - to $42-\mathrm{kDa}$ protein was selectively retained at the top of the gel (data not shown). The apparent molecular mass of the $25-\mathrm{kDa}$ protein was reduced to about $22 \mathrm{kDa}$, which would correspond with the removal of one $\mathrm{N}$-linked oligosaccharide. The $14-$ and $16-\mathrm{kDa}$ proteins were resistant to glyco $\mathrm{F}$ digestion, which indicates that they lack $N$-glycans.

Immunoprecipitations were done on ${ }^{35}$ S $]$ methionine-labeled virus, using an antiserum directed against virions collected from a sucrose gradient. The antivirion serum specifically recognized the $14-, 16-$, and $30-$ to $42-\mathrm{kDa}$ structural proteins but not the less abundant $25-\mathrm{kDa}$ protein (Fig. 3a). When in vitro translation products of ORFs 2 to 7 were screened with the antivirion serum, only the proteins corresponding to ORFs 5,6 , and 7 were immunoprecipitated (data not shown); this indicates that the proteins encoded by these ORFs are structural.

ORF 7 encodes the 14-kDa $N$ protein. The observation that in vitro translation of RNA 7 yields a $14-\mathrm{kDa}$ protein (51), the strong recognition of the ORF 7 translation product by the antivirion serum, and the computer predictions suggested that ORF 7 encodes the $14-\mathrm{kDa} \mathrm{N}$ protein. To prove this assumption, we took advantage of the fact that ORF 7 is the only viral gene that specifies a protein lacking cysteine (Table 1). Virion preparations differentially labeled with $\left[{ }^{35} \mathrm{~S}\right]$ methionine and $\left[{ }^{35} \mathrm{~S}\right]$ cysteine were purified in a sucrose 


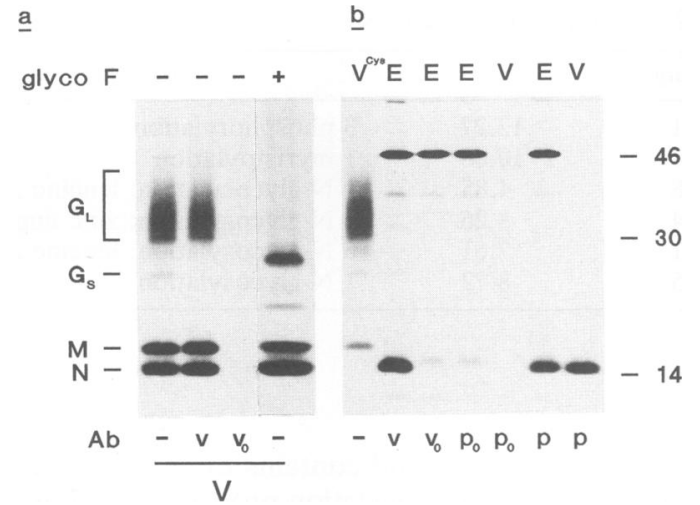

FIG. 3. (a) Protein composition of the virions of EAV. $\left[{ }^{35}\right.$ S $]$ methionine-labeled virus (V) was analyzed by SDS-PAGE directly, after treatment with glyco $F$, and after immunoprecipitation with antibodies $(\mathrm{Ab})$ directed against purified virus $(\mathrm{v})$. The corresponding preserum $\left(v_{0}\right)$ did not recognize any of the virion proteins. The positions of the $14-\mathrm{kDa}$ protein $(\mathrm{N})$, the $16-\mathrm{kDa}$ protein $(\mathrm{M})$, and the $25-\mathrm{kDa}$ protein $\left(\mathrm{G}_{\mathrm{S}}\right)$ are indicated; the bracket depicts the size limits of the heterogeneously glycosylated 30 - to $42-\mathrm{kDa}$ protein $\left(\mathrm{G}_{\mathrm{L}}\right)$. (b) Characterization of the EAV ORF 7 expression product. BHK-21 cells were infected with vaccinia virus recombinant VAVE07 and labeled at $5 \mathrm{~h}$ p.i. with $\left[{ }^{35} \mathrm{~S}\right]$ methionine for $20 \mathrm{~min}$. The resulting cell lysate was incubated with the antivirion serum (v), an antipeptide serum specific for the ORF 7 protein (p), or the corresponding presera $\left(\mathrm{v}_{0}\right.$ and $\left.\mathrm{p}_{0}\right)$. The immunoprecipitated expression product was analyzed by SDS-PAGE (lanes E). For comparison, the antipeptide serum and its corresponding preserum were applied to ${ }^{[35}$ S $]$ methionine-labeled virus (lanes $\mathrm{V}$ ). $\mathrm{V}^{\text {Cys }}$ denotes a $\left[{ }^{35} \mathrm{~S}\right]$ cysteine-labeled virus preparation. The positions and sizes (in kilodaltons) of marker proteins analyzed in the same gel are indicated at the right.

gradient, and the protein patterns were compared by SDSPAGE. The $14-\mathrm{kDa}$ protein prominent in $\left.{ }^{35} \mathrm{~S}\right]$ methioninelabeled virions (Fig. 3a) was absent in the $\left[{ }^{35} \mathrm{~S}\right]$ cysteinelabeled preparation (Fig. $3 b$ ). Both radioactive amino acids were incorporated into the other structural proteins; the $16-\mathrm{kDa}$ protein was poorly labeled with $\left[{ }^{35} \mathrm{~S}\right] \mathrm{cysteine}$.

We then constructed the vaccinia virus recombinant vAVE07 expressing ORF 7 under the control of the vaccinia virus $7.5-\mathrm{kDa}$ early-late promoter. BHK-21 cells were infected with vAVE07 and labeled with Tran $\left[{ }^{35}\right.$ S]-label. Newly synthesized proteins were immunoprecipitated with the antivirion serum and separated by SDS-PAGE. The antiserum specifically recognized a $14-\mathrm{kDa}$ protein which comigrated with the smallest virion protein (Fig. $3 b$ ). The same protein was immunoprecipitated with an antiserum raised against the 18 carboxy-terminal amino acids of the predicted ORF 7 product; the antipeptide serum also recognized the $14-\mathrm{kDa}$ protein in a virus preparation. The corresponding presera failed to bind a protein of $14 \mathrm{kDa}$. The combined data confirm the identity of ORF 7 as the gene encoding the 14-kDa $\mathrm{N}$ protein.

ORF 6 encodes the 16-kDa $M$ protein. The predicted ORF 6 product has a molecular weight close to 16,000 , lacks $\mathrm{N}$-glycosylation sites, and contains five methionines and one cysteine (Table 1). In vitro translation of ORF 6 yielded a protein of the anticipated size that was recognized by the antivirion serum (data not shown). Moreover, like the $\mathbf{N}$ protein, the $16-\mathrm{kDa}$ protein is a virion constituent lacking $N$-glycans (Fig. 3a). Together with the inferior incorporation

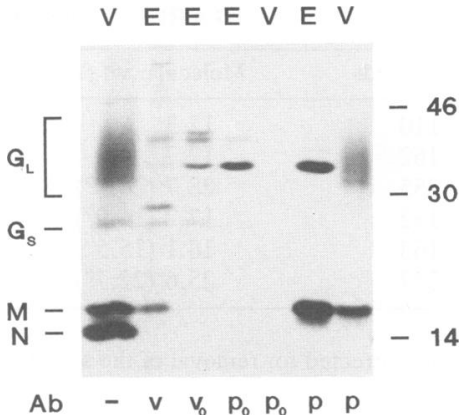

FIG. 4. Characterization of the EAV ORF 6 expression product. BHK-21 cells were transfected with pAVI16, infected with recombinant vaccinia virus VTF7-3 at $5 \mathrm{~h}$ posttransfection, and labeled for 20 min with $\left[{ }^{35} S\right]$ methionine $5 \mathrm{~h}$ after infection. The ORF 6 product was immunoprecipitated from the cell lysate with the antivirion serum (v) or a specific antipeptide serum (p), and the immunoprecipitates were analyzed by SDS-PAGE (lanes E). The protein patterns were compared with those of $\left[{ }^{35} \mathrm{~S}\right]$ methionine-labeled virus applied to the gel directly or after immunoprecipitation with the antipeptide serum (lanes $\mathrm{V})$. The corresponding presera $\left(\mathrm{v}_{0}, \mathrm{p}_{0}\right)$ failed to immunoprecipitate the ORF 6 protein from both the transfected cells and the virus preparation. $\mathrm{Ab}$, antibody. Numbers on right show size in kilodaltons.

of $\left[{ }^{35} \mathrm{~S}\right]$ cysteine (Fig. $3 \mathrm{~b}$ ), these data indicate that the $16-\mathrm{kDa}$ structural protein is encoded by ORF 6 .

To prove this point, we expressed ORF 6 in vivo using the vaccinia $\mathrm{T} 7$ transient expression system (13). For this purpose, we constructed the plasmid pAVI16, which has ORF 6 cloned behind a T7 promoter. BHK-21 cells were transfected with the plasmid and infected with recombinant vaccinia virus vTF7-3 synthesizing the bacteriophage T7 RNA polymerase. The cells were metabolically labeled, and the expression product was immunoprecipitated with the antivirion serum or an antipeptide serum raised against the carboxy terminus of the predicted ORF 6 protein. As shown in Fig. 4, a 16-kDa protein indistinguishable from that in the $\left[{ }^{35} \mathrm{~S}\right]$ methionine-labeled virus preparation was detected with both antisera but not with the corresponding presera. The antivirion serum also recognized a protein of $28 \mathrm{kDa}$, in contrast to the antipeptide serum. We have indications that this protein is a dimer of the ORF 6 product formed during the analytical procedures. A strong tendency to aggregate has also been reported for the coronavirus $M$ protein, which (as we justify in the Discussion) is very similar to the EAV ORF 6 product. The inability of the antipeptide serum to immunoprecipitate the dimer may be attributed to the stringent immunoprecipitation conditions ( $0.25 \%$ SDS), which would prevent complex formation. Alternatively, the antipeptide serum may fail to precipitate the dimer because the aggregation renders the carboxy-terminal epitope on the ORF 6 protein inaccessible for the antibodies.

To complete the evidence that ORF 6 encodes the $16-\mathrm{kDa}$ virion protein, we subjected $\left[{ }^{35} \mathrm{~S}\right]$ methionine-labeled virus to immunoprecipitation using the antipeptide serum and analyzed it by SDS-PAGE. The $16-\mathrm{kDa}$ virion protein was clearly recognized by the antipeptide serum (Fig. 4). However, a substantial amount of the $30-$ to $42-\mathrm{kDa}$ protein was also precipitated. The corresponding preserum did not recognize the smear. The coprecipitation of the $30-$ to $42-\mathrm{kDa}$ protein presumably results from a specific association with the $16-\mathrm{kDa}$ protein as it is unlikely that both proteins share a common epitope that is recognized by the antipeptide serum. 
$\underline{a}$

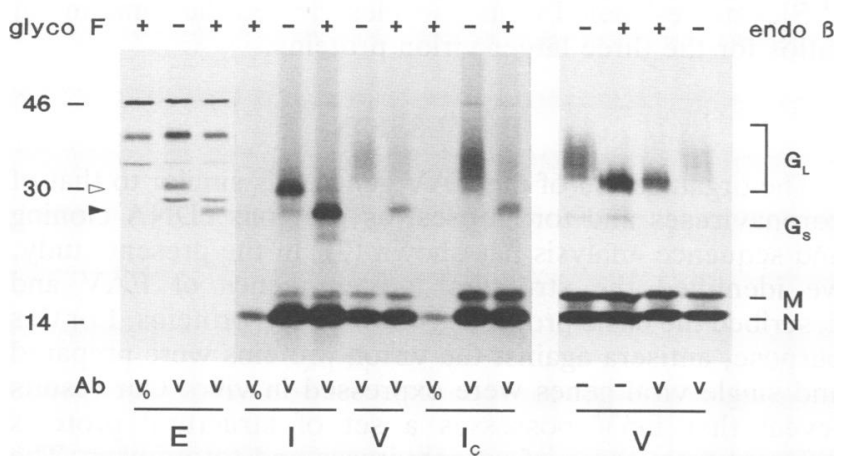

FIG. 5. Characterization of the EAV ORF 5 expression product. (a) BHK-21 cells were transfected with pAVI15, infected with vTF7-3 at $5 \mathrm{~h}$ posttransfection, and labeled for $20 \mathrm{~min}$ with $\left[{ }^{35} \mathrm{~S}\right] \mathrm{me}-$ thionine $5 \mathrm{~h}$ after infection (lanes E). EAV-infected BHK-21 cells were labeled with $\left[{ }^{35}\right.$ S]methionine for the same period at $8 \mathrm{~h}$ p.i. (lanes I). Alternatively, the 20-min pulse-labeling of EAV-infected cells was followed by a 2 -h chase (lanes $I_{c}$ ). The ORF 5 protein was immunoprecipitated from the cell lysates and from a $\left[{ }^{35} S\right]$ methionine-labeled virus preparation (lanes $V$ ) with the antivirion serum (v). Immunoprecipitations with the corresponding preserum $\left(\mathrm{v}_{0}\right)$ were included as a control. The immunoprecipitates were treated $(+)$ or mock treated (-) with glyco F and analyzed by SDS-PAGE. The position of the glycosylated ORF 5 product obtained after a 20 -min pulse is indicated by an open arrowhead. The closed arrowhead points to the glyco F-treated ORF 5 protein. (b) $\left[{ }^{35} \mathrm{~S}\right]$ methionine-labeled virus (V) was treated $(+)$ or mock treated $(-)$ with endo- $\beta$ both directly and after immunoprecipitation with the antivirion serum (v) as described in Materials and Methods. Ab, antibody. Numbers on left show size in kilodaltons.

The observation that the antivirion serum reacts strongly with the ORF 6 protein from a virus preparation and only weakly with the ORF 6 product synthesized in pAVI16transfected cells is an additional indication of a specific association between the $16-$ and $30-$ to $42-\mathrm{kDa}$ proteins.

ORF 5 encodes the heterogeneously glycosylated 30- to 42-kDa $\left(G_{L}\right)$ protein. The predicted ORF 5 product has a molecular weight of 28,700 and contains one potential N-glycosylation site (Table 1). In vitro translation of ORF 5 in the presence of microsomes yielded a $30-\mathrm{kDa}$ protein which was strongly recognized by the antivirion serum. Its apparent molecular weight was reduced to 27,000 after glyco $F$ treatment (data not shown). Since the same molecular weight was observed for the glyco F-digested 30 - to $42-\mathrm{kDa}$ virion protein (Fig. 3a), we speculated that ORF 5 encodes the $30-$ to $42-\mathrm{kDa}$ smear.

To study the ORF 5 expression product, we cloned its coding sequence downstream of a $T 7$ promoter. The resulting plasmid, designated pAVI15, was transfected into BHK-21 cells which were subsequently infected with vTF7-3 and labeled for $20 \mathrm{~min}$ with $\operatorname{Tran}\left[{ }^{35} \mathrm{~S}\right]$-label at $5 \mathrm{~h}$ p.i. An immunoprecipitate was prepared by using the antivirion serum, divided in two equal parts, treated or mock treated with glyco F, and analyzed by SDS-PAGE. In the absence of the endoglycosidase, a discrete $30-\mathrm{kDa}$ product was resolved (Fig. 5a). It probably contains one $\mathrm{N}$-linked oligosaccharide because its molecular weight was reduced to 27,000 by the glyco F treatment. A $30-\mathrm{kDa}$ protein was also immunoprecipitated from a lysate of EAV-infected cells labeled for the same period. Glyco $\mathrm{F}$ digestion converted this protein into a 27-kDa species which comigrated not only with the deglycosylated form of the ORF 5 expression product but also with that of the 30 - to $42-\mathrm{kDa}$ protein from virions. The weak band observed below the $30-\mathrm{kDa}$ band probably represents a degradation product of the $30-\mathrm{kDa}$ protein since it was equally affected by the glyco $\mathrm{F}$ treatment. Collectively, these data indicate that the proteins of 30 and 30 to $42 \mathrm{kDa}$ are different glycoforms of the same polypeptide.

The 30 - to $42-\mathrm{kDa}$ protein conceivably derives from the 30-kDa protein by maturation of its $\mathrm{N}$-linked oligosaccharide side chain during transport from the endoplasmic reticulum through the Golgi apparatus. To prove this assumption, EAV-infected BHK-21 cells were pulse-labeled for $20 \mathrm{~min}$ and then chased for $2 \mathrm{~h}$. Analysis of an immunoprecipitate obtained with the antivirion serum revealed that the $30-\mathrm{kDa}$ protein observed after pulse-labeling had been processed to a smear of 28 to $42 \mathrm{kDa}$, comparable to that in the [ ${ }^{35} \mathrm{~S}$ ]methionine-labeled virus preparation (Fig. 5a). The chase had no detectable effect on the 12- and 14-kDa proteins; these probably do not undergo extensive posttranslational modifications. When the immunoprecipitate was treated with glyco $\mathrm{F}$, the smear was converted into the $27-\mathrm{kDa}$ protein identified before.

The inability to completely digest the smear reflects a technical problem rather than the occurrence of glyco F-resistant oligosaccharides. The same phenomenon was observed with the 30 - to $42-\mathrm{kDa}$ protein immunoprecipitated from the $\left[{ }^{35} \mathrm{~S}\right]$ methionine-labeled virus preparation. To minimize aggregation of the ORF 5 protein, the digestions had to be done in suspension with the immune complexes still attached to the $S$. aureus cells. Unfortunately, this often resulted in partial digestion which was not overcome by the addition of more enzyme. In contrast, when the glyco $F$ treatment was performed on $\left[{ }^{35} \mathrm{~S}\right]$ methionine-labeled virus directly from a sucrose gradient, the 30 - to $42-\mathrm{kDa}$ protein was fully converted to the $27-\mathrm{kDa}$ protein (Fig. $3 \mathrm{a}$ ).

The appearance of a smear during the chase suggested to us that the ORF 5 protein acquired either multiple sialic acid residues or a polylactosaminoglycan (26). Since ORF 5 encodes a rather acidic polypeptide (Table 1 ), we considered polysialylation unlikely. To investigate whether the heterogeneous electrophoretic mobility is due to poly- $N$-acetyllactosamine formation, we treated $\left[{ }^{35} \mathrm{~S}\right]$ methionine-labeled virions with endo- $\beta$. This enzyme cleaves the internal $\beta 1 \rightarrow 4$ galactosidic linkages of oligosaccharides with the general sequence R-GlcNAc $\beta 1 \rightarrow 3$ Gal $\beta 1 \rightarrow 4$ GlcNAc/Glc-R' ${ }^{\prime}$ (47). Whereas the $25-\mathrm{kDa}$ glycoprotein was resistant to endo- $\beta$ treatment, the $30-$ to $42-\mathrm{kDa}$ smear was converted to a discrete band of $30 \mathrm{kDa}$ (Fig. 5b). A similar result was obtained when $\left[{ }^{35}\right.$ S]methionine-labeled virion proteins, immunoprecipitated with the antivirion serum, were treated in suspension with endo- $\beta$. The slight size difference between the glyco $F$ - and endo- $\beta$-treated ORF 5 protein reflects the fact that the latter leaves part of the $N$-linked oligosaccharide side chain intact. The susceptibility to endo- $\beta$ strongly suggests that the ORF 5 protein contains a polylactosaminoglycan.

After the 2-h chase period, considerably more of the ORF 6 protein was immunoprecipitated than after the pulse. Efficient precipitation of the ORF 6 protein by the antivirion serum may rely on its interaction with the ORF 5 protein; complex formation between these two would require (partial) maturation of the ORF 5 and/or ORF 6 proteins. The failure of the ORF 6-specific antipeptide serum to recognize the expression product of ORF 5 (data not shown) together with its ability to coprecipitate a substantial portion of the ORF 5 protein from a virus preparation (Fig. 4) provides 


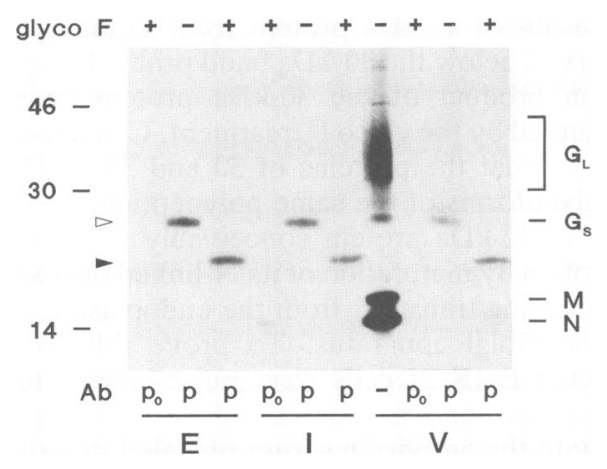

FIG. 6. Characterization of the EAV ORF 2 expression product. BHK-21 cells were transfected with pAVI02, infected with vTF7-3 at $5 \mathrm{~h}$ posttransfection, and labeled for $20 \mathrm{~min}$ with $\left[{ }^{35} \mathrm{~S}\right]$ methionine $5 \mathrm{~h}$ p.i. (lanes E). EAV-infected BHK-21 cells were labeled with $\left[{ }^{35} \mathrm{~S}\right]$ methionine for the same period at $8 \mathrm{~h}$ p.i. (lanes I). The ORF 2 protein was immunoprecipitated from the cell lysates and from a ${ }^{35}$ S]methionine-labeled virus preparation (lanes $\mathrm{V}$ ) with a specific antipeptide serum (p). Immunoprecipitation with the corresponding preserum $\left(\mathrm{p}_{0}\right)$ were done as a control. The immunoprecipitates were treated $(+)$ or mock treated $(-)$ with glyco $F$ and analyzed by SDS-PAGE together with $\left[{ }^{35}\right.$ S $]$ methionine-labeled virus. The open arrowhead marks the position of the glycosylated ORF 2 product, and the closed arrowhead points to the ORF 2 product obtained after digestion with glyco F. Ab, antibody. Numbers on left show size in kilodaltons.

further evidence for an association between the ORF 5 and 6 proteins.

ORF 2 encodes the glycosylated $25-k D a\left(G_{S}\right)$ protein. Once the three major structural proteins of EAV were assigned to ORFs 5,6 , and 7 , ORF 2 remained as the most likely candidate to encode the minor $25-\mathrm{kDa}$ virion protein. The translation product of ORF 2 contains a single $\mathrm{N}$-glycosylation site and has a calculated molecular weight of 22,700 after removal of its predicted amino-terminal signal sequence (Table 1). For this reason, ORF 2 was cloned behind a $\mathrm{T} 7$ promoter and expressed in BHK-21 cells utilizing the vaccinia virus recombinant vTF7-3. After metabolic labeling for $20 \mathrm{~min}$, the expression product of ORF 2 was immunoprecipitated from the cell lysate with an antipeptide serum raised against the predicted carboxy terminus of the ORF 2 protein. The antiserum was also applied to a lysate of EAV-infected BHK-21 cells which were labeled for the same time span and to a preparation of $\left[{ }^{35} \mathrm{~S}\right]$ methionine-labeled virions. The resulting immunoprecipitates were each split in two portions which were treated or mock treated with glyco $\mathrm{F}$ and analyzed by SDS-PAGE. In all cases, the antipeptide serum recognized a $25-\mathrm{kDa}$ protein which was converted to a $22-\mathrm{kDa}$ protein after treatment with glyco $\mathrm{F}$ (Fig. 6). This result unequivocally identified the $\mathrm{N}$-glycosylated $25-\mathrm{kDa}$ protein as the product of ORF 2.

Quantification of structural proteins. The identification of the structural protein genes of EAV enabled us to determine the molar ratios of the proteins in the virion. $\left[{ }^{35} \mathrm{~S}\right]$ methionine-labeled virus particles were analyzed on a gel, and the amount of radioactivity incorporated into each component was measured and divided by the predicted number of methionines in that particular protein. The calculations were based on the assumption that the signal sequences of the glycoproteins and the amino-terminal methionine of the two smaller structural proteins are cleaved. In this way, the molar ratios of the $N, M$, and $G_{L}$ proteins were determined to be approximately $3: 2: 3$. The $G_{s}$ protein was about 25 times less abundant than the $\mathbf{N}$ protein. A similar analysis of $\left.{ }^{35} \mathrm{~S}\right]$ cysteine-labeled virus particles yielded the same molar ratios for the three larger virion proteins.

\section{DISCUSSION}

The organization of the EAV genome is similar to that of coronaviruses and toroviruses, as previous cDNA cloning and sequence analysis has shown (7). In the present study, we identified the structural protein genes of EAV and described the basic properties of the virion proteins. For this purpose, antisera against the virion proteins were prepared and single viral genes were expressed in vivo. Our results reveal that EAV possesses a set of structural proteins different from those of coronaviruses and toroviruses. The virion contains four polypeptides; a nucleocapsid protein of $14 \mathrm{kDa}$ and three envelope proteins of 16, 25, and 30 to 42 kDa. We designated these proteins $N, M, G_{S}$, and $G_{L}$, respectively.

The two largest proteins are $\mathrm{N}$-glycosylated as judged by their sensitivity to digestion with glyco F. Although both contain a single $N$-glycan and travel through the same intracellular compartments in the context of a virus particle, maturation of their $\mathrm{N}$-linked oligosaccharide side chains is different. The mature $G_{L}$ protein is susceptible to digestion with endo- $\beta$, which indicates that it becomes glycosylated by the addition of variable numbers of lactosamine (Gal $\beta 1 \rightarrow$ $4 \mathrm{GlcNAc} \beta 1 \rightarrow 3$ ) repeats to the $\mathrm{N}$-linked core oligosaccharide. The extracellular $G_{S}$ protein is resistant to treatment with endo- $\beta$ and endoglycosidase $H$ (data not shown) and therefore probably acquires a regular complex type $\mathrm{N}$-glycan. The relatively long pulse-labeling that we employed ( 20 min) leaves the possibility that the virion proteins acquired early posttranslational modifications which remained unnoticed. The absence of detectable size differences between the glyco F-treated proteins from pulse-labeled cells and from radiolabeled virions does not exclude late processing events that would cause only subtle changes in molecular weight. The $M$ protein could not be labeled with $\left[{ }^{3} \mathrm{H}\right]$ glucosamine, indicating that it is neither N-glycosylated nor O-glycosylated (24).

The addition of poly- $N$-acetyllactosamine is thought to occur in the trans cisternae of the Golgi apparatus and/or in the trans-Golgi network $(46,53)$. It is presently unknown which features of a protein determine polylactosaminoglycan formation. Several investigators have suggested that the addition of poly- $N$-acetyllactosamine requires an $N$-glycan to be in close proximity to the Golgi membrane $(14,56)$. It is hard to imagine how this requirement can be fulfilled for $G_{L}$, which is incorporated into virions before traversing the Golgi complex. To date, the only other viral protein known to acquire a polylactosaminoglycan is the NB protein of influenza $B$ virus (56). Here, the addition of polylactosaminoglycans precedes virus assembly, as budding occurs at the plasma membrane. The function of the poly- $N$-acetyllactosamine modification attached to $G_{L}$ is unclear. The polylactosaminoglycan of lysosomal membrane glycoproteins apparently contributes to their stability by protecting the polypeptide moiety from proteolytic digestion (31). The unique poly- $N$-acetyllactosamine structures in granulocytes and monocytes serve as ligands for adhesion molecules (selectins) present on endothelial cells and platelets (12). It would be of interest to investigate whether the polylactosaminoglycan of $G_{L}$ is involved in receptor binding.

The $N$ and $G_{L}$ proteins each compose 35 to $40 \%$ of the protein moiety in the EAV particle. The M protein is slightly 
less abundant, and $\mathrm{G}_{\mathrm{S}}$ represents only 1 to $2 \%$ of the virion protein on a molar basis. The presence of equimolar amounts of $M$ and $G_{S}$ in virus-infected cells (data not shown) suggests an important function for the intracellular counterpart of $G_{S}$ and indicates that it is only incidentally incorporated in virus particles. A similar discrepancy between the amounts present in cells and virions has been observed for the $\mathbf{M}_{2}$ protein of influenza A virus (57). The existence of additional virion proteins which are present in low amounts or have been lost during virus preparation cannot be excluded. However, four structural proteins were also found by others. No additional species were detected when the virus was collected by high-speed pelleting as an alternative to PEG precipitation (51). The four previously described envelope glycoproteins in the size range of 28 to $40 \mathrm{kDa}(24)$ most probably correspond to the 30 - to $42-\mathrm{kDa}$ structural protein identified here; this would mean that the same virion proteins are observed after labeling with $\mathrm{L}-\left[{ }^{14} \mathrm{C} /{ }^{3} \mathrm{H}\right]$ amino acids instead of $\mathrm{L}-\left[{ }^{35} \mathrm{~S}\right]$ methionine $(24,58)$. Apart from the inconsistent appearance of $G_{L}$, essentially the same protein set was seen after propagation of EAV in BHK-21, RK-13, and Vero cells (58). The variations in size of $G_{L}$ may reflect cell-type-dependent differences in the maturation of the polylactosaminoglycan (56). The $21-\mathrm{kDa}$ protein reported earlier $(51,58)$ is probably a cellular contaminant: a prominent protein species of this size was observed after PEG precipitation of culture medium from mock-infected BHK-21 cells (data not shown). Alternatively, it may have been confused with $G_{S}$ or may constitute a discrete degradation product of $G_{L}$.

The major structural proteins $N, M$, and $G_{L}$ are encoded by ORFs 7,6 , and 5 , respectively; the minor virion glycoprotein $\mathrm{G}_{\mathrm{S}}$ is encoded by ORF 2 . The expression products of EAV ORFs 3 and 4 have only been characterized in vitro. In the presence of microsomes, ORF 3 directed the synthesis of a glycoprotein of approximately $45 \mathrm{kDa}$ with multiple functional $\mathrm{N}$-glycosylation sites. In vitro translation of ORF 4 yielded a labile protein of $16 \mathrm{kDa}$ which migrated slightly faster than the in vitro translation product of ORF 6 (data not shown). Since all proteins in the glyco F-treated virus preparation are assigned and their in vitro translation products are not recognized by the antivirion serum, we expect ORFs 3 and 4 to encode nonstructural proteins.

The properties of the structural proteins fit the computer predictions (Table 1). The calculated sizes of the $\mathbf{N}$ and $\mathbf{M}$ proteins are in good agreement with the molecular weights estimated from gels. The apparent molecular weight of $G_{S}$ after glyco $F$ treatment suggests that the signal sequence of this protein is removed during membrane insertion. It is unclear whether $G_{L}$ is cleaved by the signal peptidase because its predicted signal sequence is rather short. The observation that $\mathbf{N}$ is phosphorylated (58) is consistent with the presence of three potential phosphorylation sites. A good correlation also exists between the presence of $\mathrm{N}$-glycosylation sites and the glyco $F$ sensitivity of the structural proteins.

The virion architecture has not been formally established but was inferred from the properties of the structural proteins and from virus fractionation experiments. After detergent treatment of virus particles, only the smallest virion protein cosedimented with the viral genome in a sucrose gradient $(24,58)$. This indicates that the $14-\mathrm{kDa}$ virion protein corresponds to the nucleocapsid protein and implies that the other structural proteins are either envelope or matrix proteins. $G_{S}$ probably represents a type I integral membrane protein as deduced from the position of its
$\mathrm{N}$-glycosylation site with respect to the predicted stoptransfer signal. The membrane topology of $G_{L}$ is still unclear; its long internal hydrophobic domain may allow for up to three membrane-spanning segments. The hydropathy profile of the ORF 6 protein is remarkably similar to that of the membrane protein of coronaviruses and of the envelope protein of toroviruses $(8,44)$. Protease protection experiments have shown that the $\mathbf{M}$ proteins of mouse hepatitis virus strain A59 and infectious bronchitis virus are type III integral membrane proteins which contain three successive transmembrane domains $(4,43)$. It is likely that the $M$ protein of EAV has a similar membrane topology. We anticipate that the $M$ proteins of EAV and coronaviruses are functional homologs.

A comparison of the structural proteins of EAV with those of other viruses reveals a striking similarity with the virion proteins of lactate dehydrogenase-elevating virus (LDV) and simian hemorrhagic fever virus (SHFV). The virus particles of LDV have been reported to contain a nucleocapsid protein of 13 to $15 \mathrm{kDa}$, a nonglycosylated envelope protein of 17 to $19 \mathrm{kDa}$, and probably one envelope glycoprotein of 24 to $44 \mathrm{kDa}(3,18,35)$. Although the structural proteins of SHFV have not been characterized in detail, the SDS-PAGE profile of virions labeled with ${ }^{14} \mathrm{C}$-amino acids resembles those of EAV and LDV (49). No antigenic relationship was found between the three viruses $(41,52)$, but $L D V$ and SHFV share a number of other properties with EAV: the primary target cell of all three viruses in their respective hosts is the macrophage; they establish asymptomatic persistent infections in their natural hosts; assembly of virus particles occurs by budding from intracellular membranes; virion morphology and physicochemical properties are similar. The viral genomes consist of a polyadenylated positivestranded genomic RNA of approximately the same length (41). Recently, a 3'-coterminal nested set of seven leadercontaining viral subgenomic RNAs was identified in LDVinfected macrophages $(27,28)$. Moreover, nucleotide sequencing indicated that LDV has a genome organization identical to that of EAV and demonstrated that LDV is more closely related to EAV than to coronaviruses $(15,27,28)$. Interestingly, the newly discovered porcine reproductive and respiratory syndrome virus also shares some properties with EAV and LDV (40).

On the basis of the combined available data, we propose to classify EAV, LDV, and SHFV as belonging to the same taxonomic cluster, with evolutionary links to the family Coronaviridae. However, coronaviruses and toroviruses, the two established genera in this family, are sufficiently different from arteriviruses to exclude their classification at the same hierarchic level.

\section{ACKNOWLEDGMENTS}

We thank L. N. Fernie and E. C. A. Freund for peptide synthesis. Use of the services and facilities of the Dutch National Expertise Cenet CAOS/CAMM, under grant numbers SON 326-052 and STW NCH99.1751, is gratefully acknowledged. This work was supported by a research grant from Duphar BV, Weesp, The Netherlands.

\section{REFERENCES}

1. Bairoch, A. 1991. PROSITE: a dictionary of sites and patterns in proteins. Nucleic Acids Res. Suppl. 19:2241-2242.

2. Bonner, W. M., and R. A. Laskey. 1974. A film detection method for tritium-labelled proteins and nucleic acids in polyacrylamide gels. Eur. J. Biochem. 46:83-88.

3. Brinton-Darnell, M., and P. G. W. Plagemann. 1975. Structure and chemical-physical characteristics of lactate dehydrogenaseelevating virus and its RNA. J. Virol. 16:420-433. 
4. Cavanagh, D., P. J. Davis, and D. J. C. Pappin. 1986. Coronavirus IBV glycopolypeptides: locational studies using proteases and saponin, a membrane permeabilizer. Virus Res. 4:145-156.

5. Chakrabarti, S., K. Brechling, and B. Moss. 1985. Vaccinia virus expression vector: coexpression of $\beta$-galactosidase provides visual screening of recombinant virus plaques. Mol. Cell. Biol. 5:3403-3409.

6. Chirnside, E. D. 1992. Personal communication

7. den Boon, J. A., E. J. Snijder, E. D. Chirnside, A. A. F. de Vries, M. C. Horzinek, and W. J. M. Spaan. 1991. Equine arteritis virus is not a togavirus but belongs to the coronaviruslike superfamily. J. Virol. 65:2910-2920.

8. den Boon, J. A., E. J. Snijder, J. Krijnse Locker, M. C. Horzinek, and P. J. M. Rottier. 1991. Another triple-spanning envelope protein among intracellularly budding RNA viruses: the torovirus E protein. Virology 182:655-663.

9. de Vries, A. A. F., E. D. Chirnside, P. J. Bredenbeek, L. A. Gravestein, M. C. Horzinek, and W. J. M. Spaan. 1990. All subgenomic mRNAs of equine arteritis virus contain a common leader sequence. Nucleic Acids Res. 18:3241-3247.

10. Doll, E. R., J. T. Bryans, W. H. McCollum, and M. E. W. Crowe. 1957. Isolation of a filterable agent causing arteritis of horses and abortion by mares. Its differentiation from the equine abortion (influenza) virus. Cornell Vet. 47:3-41.

11. Felgner, P. L., T. R. Gadek, M. Holm, R. Roman, H. W. Chan, M. Wenz, J. P. Northrop, G. M. Ringold, and M. Danielsen. 1987. Lipofectin: a highly efficient, lipid-mediated DNA-transfection procedure. Proc. Natl. Acad. Sci. USA 84:7413-7417.

12. Foxall, C., S. R. Watson, D. Dowbenko, C. Fennie, L. A. Lasky, M. Kiso, A. Hasegawa, D. Asa, and B. K. Brandley. 1992. The three members of the selectin receptor family recognize a common carbohydrate epitope, the sialyl Lewis ${ }^{x}$ oligosaccharide. J. Cell Biol. 117:895-902.

13. Fuerst, T. R., E. G. Niles, F. W. Studier, and B. Moss. 1986. Eukaryotic transient-expression system based on recombinant vaccinia virus that synthesizes bacteriophage T7 RNA polymerase. Proc. Natl. Acad. Sci. USA 83:8122-8126.

14. Fukuda, M., J.-L. Guan, and J. K. Rose. 1988. A membraneanchored form but not the secretory form of human chorionic gonadotropin- $\alpha$ chain acquires polylactosaminoglycan. J. Biol. Chem. 263:5314-5318.

15. Godeny, E. K., D. W. Speicher, and M. A. Brinton. 1990. Map location of lactate dehydrogenase-elevating virus (LDV) capsid protein $(\mathrm{Vp} 1)$ gene. Virology 177:768-771.

16. Gorman, C. 1985. High efficiency gene transfer into mammalian cells, p. 143-190. In D. M. Glover (ed.), DNA cloning, vol. II. IRL Press, Oxford.

17. Gullick, W. J., J. Downward, and M. D. Waterfield. 1985. Antibodies to the autophosphorylation sites of the epidermal growth factor receptor protein-tyrosine kinase as probes of structure and function. EMBO J. 4:2869-2877.

18. Harty, J. T., and P. G. W. Plagemann. 1988. Formalin inactivation of the lactate dehydrogenase-elevating virus reveals a major neutralizing epitope not recognized during natural infection. J. Virol. 62:3210-3216.

19. Horzinek, M., J. Maess, and R. Laufs. 1971. Studies on the substructure of togaviruses. II. Analysis of equine arteritis, rubella, bovine viral diarrhea, and hog cholera viruses. Arch. Gesamte Virusforsch. 33:306-318.

20. Horzinek, M. C. 1981. Non-arthropod-borne togaviruses. Academic Press, Inc. (London), Ltd., London.

21. Horzinek, M. C., J. A. den Boon, E. J. Snijder, E. D. Chirnside, A. A. F. de Vries, and W. J. M. Spaan. 1992. The virus of equine arteritis, p. 201-205. In W. Plowright, P. D. Rossdale, and J. F. Wade (ed.), Proceedings of the 6th International Conference on Equine Infectious Diseases, Cambridge 1991. R\&W Publications, Ltd., Newmarket, England.

22. Huntington, P. J., P. M. Ellis, A. J. Forman, and P. J. Timoney. 1990. Equine viral arteritis. Aust. Vet. J. 67:429-431.

23. Huntington, P. J., A. J. Forman, and P. M. Ellis. 1990. The occurrence of equine arteritis virus in Australia. Aust. Vet. J. 67:432-435.

24. Hyllseth, B. 1973. Structural proteins of equine arteritis virus.
Arch. Gesamte Virusforsch. 40:177-180.

25. Hyllseth, B., P. Magnusson, and H. Marusyk. 1970. Studies on equine arteritis virus, p. 140-142. In J. T. Bryans and H. Gerber (ed.), Proceedings of the 2nd International Conference on Equine Infectious Diseases, Paris 1969. S. Karger, Basel.

26. Kornfeld, R., and S. Kornfeld. 1985. Assembly of asparaginelinked oligosaccharides. Annu. Rev. Biochem. 54:631-664.

27. Kuo, L., Z. Chen, R. R. R. Rowland, K. S. Faaberg, and P. G. W. Plagemann. 1992. Lactate dehydrogenase-elevating virus (LDV): subgenomic mRNAs, mRNA leader and comparison of 3'-terminal sequences of two LDV isolates. Virus Res. 23:55-72.

28. Kuo, L., J. T. Harty, L. Erickson, G. A. Palmer, and P. G. W. Plagemann. 1991. A nested set of eight RNAs is formed in macrophages infected with lactate dehydrogenase-elevating virus. J. Virol. 65:5118-5123.

29. Kyte, J., and R. F. Doolittle. 1982. A simple method for displaying the hydropathic character of a protein. J. Mol. Biol. 157:105-132.

30. Laemmli, U. K. 1970. Cleavage of structural proteins during the assembly of the head of bacteriophage T4. Nature (London) 227:680-685.

31. Lee, N., W.-C. Wang, and M. Fukuda. 1990. Granulocyte differentiation of HL-60 cells is associated with increase of poly- $N$-acetyllactosamine in Asn-linked oligosaccharides attached to human lysosomal membrane glycoproteins. J. Biol. Chem. 265:20476-20487.

32. Mackett, M., G. L. Smith, and B. Moss. 1985 . The construction and characterisation of vaccinia virus recombinants expressing foreign genes, p. 191-211. In D. M. Glover (ed.), DNA cloning, vol. II. IRL Press, Oxford.

33. Magnusson, P., B. Hyllseth, and H. Marusyk. 1970. Morphological studies on equine arteritis virus. Arch. Gesamte Virusforsch. 30:105-112.

34. McCollum, W. H., and J. T. Bryans. 1973. Serological identification of infection by equine arteritis virus in horses of several countries, p. 256-263. In J. T. Bryans and H. Gerber (ed.), Proceedings of the 3rd International Conference on Equine Infectious Diseases, Paris 1972. S. Karger, Basel.

35. Michaelides, M. C., and S. Schlesinger. 1973. Structural proteins of lactic dehydrogenase virus. Virology 55:211-217.

36. Moraillon, A., and R. Moraillon. 1978. Results of a serological survey of viral arteritis in France and in several European and African countries, p. 467-473. In J. T. Bryans and H. Gerber (ed.), Proceedings of the 4th International Conference on Equine Infectious Diseases, Lyon 1976. Veterinary Publications, Inc., Princeton, N.J.

37. Mumford, J. A. 1985. Preparing for equine arteritis. Equine Vet. J. 17:6-11.

38. Murphy, T. W., P. J. Timoney, and W. H. McCollum. 1988. Analysis of genetic variation among strains of equine arteritis virus, p. 3-12. In D. G. Powell (ed.), Proceedings of the 5th International Conference on Equine Infectious Diseases, The University Press of Kentucky, Lexington, Ky. Lexington 1987.

39. Neu, S. M., P. J. Timoney, and W. H. McCollum. 1988. Persistent infection of the reproductive tract in stallions experimentally infected with equine arteritis virus, p. 149-154. In D. G. Powell (ed.), Proceedings of the 5th International Conference on Equine Infectious Diseases, The University Press of Kentucky, Lexington, Ky. Lexington 1987.

40. Ohlinger, V. F., F. Weiland, B. Haas, N. Visser, R. Ahl, T. C. Mettenleiter, E. Weiland, H.-J. Rziha, A. Saalmüller, and O. C. Straub. 1991. Der seuchenhafte Spätabort beim Schwein-Ein Beitrag zur Ätiologie des porcine reproductive and respiratory syndrome (PRRS). Tieraerztl. Umsch. 46:703-708.

41. Plagemann, P. G. W., and V. Moennig. 1992. Lactate dehydrogenase-elevating virus, equine arteritis virus, and simian hemorrhagic fever virus: a new group of positive-strand RNA viruses. Adv. Virus Res. 41:99-183.

42. Porterfield, J. S., J. Casals, M. P. Chumakov, S. Y. Gaidamovich, C. Hannoun, I. H. Holmes, M. C. Horzinek, M. Mussgay, N. Oker-Blom, P. K. Russell, and D. W. Trent. 1978. Togaviridae. Intervirology 9:129-148. 
43. Rottier, P., D. Brandenburg, J. Armstrong, B. van der Zeijst, and G. Warren. 1984. Assembly in vitro of a spanning membrane protein of the endoplasmic reticulum: the E1 glycoprotein of coronavirus mouse hepatitis virus A59. Proc. Natl. Acad. Sci. USA 81:1421-1425.

44. Rottier, P. J. M., G. W. Welling, S. Welling-Wester, H. G. M. Niesters, J. A. Lenstra, and B. A. M. van der Zeijst. 1986. Predicted membrane topology of the coronavirus protein E1. Biochemistry 25:1335-1339.

45. Sambrook, J., E. F. Fritsch, and T. Maniatis. 1989. Molecular cloning: a laboratory manual, 2nd ed. Cold Spring Harbor Laboratory, Cold Spring Harbor, N.Y.

46. Sampath, D., A. Varki, and H. H. Freeze. 1992. The spectrum of incomplete $\mathrm{N}$-linked oligosaccharides synthesized by endothelial cells in the presence of brefeldin A. J. Biol. Chem. 267:4440 4455.

47. Scudder, P., K.-i. Uemura, J. Dolby, M. N. Fukuda, and T. Feizi. 1983. Isolation and characterization of an endo- $\beta$-galactosidase from Bacteroides fragilis. Biochem. J. 213:485-494.

48. Stewart, J. M., and J. D. Young. 1984. Solid phase peptide synthesis, 2nd ed. Pierce Chemical Co., Rockford, Ill.

49. Trousdale, M. D., D. W. Trent, and A. Shelokov. 1975. Simian hemorrhagic fever virus: a new togavirus. Proc. Soc. Exp. Biol. Med. 150:707-711.

50. van Berlo, M. F., M. C. Horzinek, and B. A. M. van der Zeijst. 1982. Equine arteritis virus-infected cells contain six polyadenylated virus-specific RNAs. Virology 118:345-352.
51. van Berlo, M. F., P. J. M. Rottier, W. J. M. Spaan, and M. C. Horzinek. 1986. Equine arteritis virus-induced polypeptide synthesis. J. Gen. Virol. 67:1543-1549.

52. van Berlo, M. F., J. J. W. Zeegers, M. C. Horzinek, and B. A. M. van der Zeijst. 1983. Antigenic comparison of equine arteritis virus (EAV) and lactic dehydrogenase virus (LDV); binding of staphylococcal protein A to the nucleocapsid protein of EAV. Zentralbl. Veterinaermed. Reihe B 30:297-304.

53. van den Eijnden, D. H., A. H. L. Koenderman, and W. E. C. M. Schiphorst. 1988. Biosynthesis of blood group i-active polylactosaminoglycans. J. Biol. Chem. 263:12461-12471.

54. von Heijne, G. 1986. A new method for predicting signal sequence cleavage sites. Nucleic Acids Res. 14:4683-4690.

55. Westaway, E. G., M. A. Brinton, S. Y. Gaidamovich, M. C. Horzinek, A. Igarashi, L. Kääriäinen, D. K. Lvov, J. S. Porterfield, P. K. Russell, and D. W. Trent. 1985. Togaviridae. Intervirology 24:125-139.

56. Williams, M. A., and R. A. Lamb. 1988. Polylactosaminoglycan modification of a small integral membrane glycoprotein, influenza B virus NB. Mol. Cell. Biol. 8:1186-1196.

57. Zebedee, S. L., and R. A. Lamb. 1988. Influenza A virus $M_{2}$ protein: monoclonal antibody restriction of virus growth and detection of $\mathrm{M}_{2}$ in virions. J. Virol. 62:2762-2772.

58. Zeegers, J. J. W., B. A. M. van der Zeijst, and M. C. Horzinek. 1976. The structural proteins of equine arteritis virus. Virology 73:200-205. 